\title{
ESTADO ISLÂMICO E SUA OPÇÃO DISCURSIVA PELA POLÊMICA E A VIOLÊNCIA
}

\author{
Eduardo Assunção Franco ${ }^{1}$
}

\begin{abstract}
RESUMO: Neste artigo, que investiga as estratégias discursivas que o grupo radical Estado Islâmico (EI) utiliza para divulgar suas ações violentas, no sentido de se firmar no espaço público e captar seguidores ou voluntários, partimos da hipótese que ele se vale de recursos linguísticos como o discurso profético/apocalíptico, a polêmica e o discurso propagandístico/incitação. Nosso corpus foi composto por textos divulgados pelo grupo em suas redes sociais e reunidos no site www.jihadology.net. A metodologia de pesquisa que utilizamos consistiu em selecionar três textos mais representativos e estudá-los de acordo com as categorias de análise que criamos, considerando os recursos discursivos que elegemos. $\mathrm{O}$ referencial teórico considerado por nós foi baseado em estudos sobre profecia/apocalipse feitos por Rabatel (2016 e 2019) e São João ([Séc.I d.C.],1990); pesquisas sobre polêmica realizadas por Amossy (2017), que incluiu investigações feitas por Schopenhauer (2009), KerbratOrecchioni (1980), Dascal (1998) e Coser (1964, [1956], 1970); e estudos sobre o discurso propagandístico/incitação empreendidos por Charaudeau (2010), Emediato (2019), Pereira (2008) e Dahlet (1996). Depois de analisar nosso corpus, conseguimos confirmar nossa hipótese. Nossa expectativa é de que outras pesquisas sejam realizadas para reforçar ou confrontar os resultados que obtivemos.
\end{abstract}

PALAVRAS-CHAVE: Estado Islâmico. Profecia. Polêmica. Discurso propagandístico. Incitação.

ABSTRACT: In this article, which investigates the discursive strategies that the radical Islamic State (EI) group uses to publicize its violent actions, in the sense of establishing itself in the public space and capturing followers or volunteers, we start from the hypothesis that it uses linguistic resources such as speech prophetic/apocalyptic, controversy and propaganda/incitement discourse. Our corpus was composed of texts published by the group on its social networks and gathered on the website www.jihadology.net. The research methodology we used consisted of selecting three more representative texts and studying them according to the categories of analysis that we created, considering the discursive resources that we chose. The theoretical framework considered by us was based on studies on prophecy / apocalypse made by Rabatel (2016 and 2019) and São João ([Sec. I d.C.], 1990); controversy research conducted by Amossy (2017), which included investigations by Schopenhauer (2009), KerbratOrecchioni (1980), Dascal (1998) and Coser (1964, [1956], 1970); and studies on the propaganda / incitement discourse undertaken by Charaudeau (2010), Emediato (2019), Pereira (2008) and Dahlet (1996). After analyzing our corpus, we were able to confirm our hypothesis. Our expectation is that further research will be carried out to reinforce or compare the results we obtained.

KEYWORDS: Islamic State. Prophecy. Controversy. Propaganda discourse. Incitement.

\footnotetext{
${ }^{1}$ Bolsista PNPD da Capes no POSLIN/FALE/UFMG, sob a supervisão do Professor Doutor Wander Emediato. Belo Horizonte. Minas Gerais. Brasil. E-mail: eduardodfranco@gmail.com.
} 
PERcursos Linguísticos • Vitória (ES) •v. 10 •n. 25 • 2020 • ISSN: 2236-2592 • Dossiê:

Discursos de resistência e corpos (re)existentes •

\section{Introdução}

Nosso objetivo principal, com este artigo, é analisar alguns textos divulgados pelo grupo Estado Islâmico (EI), nas redes sociais, procurando identificar marcas de discurso profético, polêmica, discurso propagandístico e de incitação. A hipótese que sustentamos é que o grupo se vale desses recursos discursivos para justificar suas ações de violência e captar voluntários para sua causa. Um dos objetivos complementares será contar a origem do Estado Islâmico, sua estruturação enquanto grupo terrorista, sua ligação com o Islamismo, o trabalho de divulgação de suas ações violentas e seu propósito de captar novos voluntários, que vão garantir a realização de suas atividades, sua expansão e manutenção, do ponto de vista financeiro.

Nossa justificativa para realização dessa pesquisa, que redundou na produção deste artigo, é tentar desvendar as estratégias linguística e de comunicação utilizadas pelo Estado Islâmico para divulgar suas ações violentas e, por meio delas, gerar o efeito de identificação e conquistar voluntários em vários países. Também apontaremos alguns dos motivos que levaram o grupo a realizar ataques terroristas contra países ocidentais e também orientais, só que nesse segundo caso considerados infiéis ao Islamismo.

A metodologia que utilizamos consistiu em selecionar textos publicados por grupos integrantes do Estado Islâmico, nas redes sociais, e coletados pelo site www.jihadology.net. Escolhemos aqueles que consideramos mais representativos, no sentido de apresentar elementos proféticos/apocalípticos, polêmicos e de incitação à ação, para compor nosso corpus. Em seguida, realizamos a análise dele, utilizando como ferramental as categorias de análise elaboradas a partir do referencial teórico que elegemos.

O arcabouço teórico montado por nós foi baseado em estudos sobre profecia/apocalipse feitos por Rabatel (2016 e 2019) e São João ([Séc. I d.C.), 1990); pesquisas sobre polêmica realizadas por Amossy (2017), que incluiu investigações feitas por Schopenhauer (2009), Kerbrat-Orecchioni (1980), Dascal (1998) e Coser (1964, [1956], 1970); e estudos sobre o discurso propagandístico/incitação empreendidos por Charaudeau (2010), Emediato (2019), Pereira (2008) e Dahlet (1996).

\section{O terrorismo e o Islamismo}

Prestes a completarem 20 anos, os atentados de 11 de setembro de 2001, ao qual me referirei posteriormente apenas como "atentados de 11 de setembro", ao Word Trade Center e à Casa Branca, nos Estados Unidos, são um marco histórico nas ações de grupos terroristas contra países desenvolvidos, no Ocidente. Sutti e Ricardo (2002, p. 6) explicam que: 
Terrorismo pode ser definido como uma intimidação coercitiva ou, mais amplamente, como o uso sistemático de assassinatos, ferimentos e destruição ou ameaças, para criar um clima de terror, para divulgar uma causa, e coagir pessoas a se submeterem aos seus objetivos. (BOGDANOR,1987, apud SUTTI \& RICARDO, 2002, p. 6)

Para Morin (2016), os atentados de 11 de setembro, que mataram cerca de 3 mil pessoas, fizeram com que os terroristas tivessem a certeza de que era possível enfrentar os Estados Unidos, país mais rico e poderoso do mundo, em termos bélicos. Eles eram ligados a grupos radicais, que se diziam motivados pela jihad ${ }^{2}$ (guerra santa) islâmica, para combater alguns segmentos da sociedade, entre eles países ricos que oprimiam e exploravam países do Oriente Médio, ligados à tradição islâmica.

Para alguns autores, os atentados de 11 de setembro foram a eclosão de uma insatisfação desses grupos radicais em relação a intervenções das grandes potências mundiais em países do Oriente Médio. Segundo Fonseca e Lasmar (2017, p. 27), "o fenômeno envolvendo combatentes estrangeiros ligados a movimentos radicais do islamismo político é relativamente recente. Esse movimento se inicia de forma mais significativa e regular após a intervenção soviética no Afeganistão, na década de 80 ”.

Nesse mesmo período, no vizinho Paquistão, mais precisamente na cidade de Hayatabad, um jovem saudita, adepto do salafismo ${ }^{3}$ e herdeiro de uma família bilionária, dava os primeiros passos para fundar uma organização para implementar os valores desse movimento: era Osama bin Laden, dando corpo à Al Qaeda. Weiss e Hassan (2015, p. 19) comentam que o mentor de bin Laden era o palestino Abdullah Azzam, autor de um livro, considerado um manifesto pelos muçulmanos afegãos, "que argumentava que os muçulmanos tinham tanto uma obrigação individual, quanto comunitária, de expulsar exércitos conquistadores ou de ocupação de suas terras sagradas".

Azzam dividia as atenções de bin Laden com outro líder jihadista em ascensão: Ayman al-Zawahiri, um cirurgião egípcio, adepto do salafismo radical. Depois de ficar preso durante um tempo, por envolvimento com grupos radicais, al-Zawahiri voltou à ativa, porém tornara-se adepto de um salafismo mais extremo. Weiss e Hassan (2015, p. 20) comentam que "ele andara

\footnotetext{
${ }^{2}$ A jihad remete à realização de um esforço individual (jihad maior: combate contra as paixões da alma, altruísmo, elevação individual) assim como ao engajamento na guerra para a promoção do Islã contra os infiéis (jihad menor). A teoria da jihad como cruzada religiosa contra os infiéis surge no século IX.

${ }^{3}$ O salafismo, segundo Weiss e Hassan (2015, p. 18), é "uma doutrina, que na sua forma contemporânea defende um retorno à pureza ideológica e às tradições do profeta Maomé. (...) Na ponta mais extrema das suas fileiras, os salafistas também são adeptos da jihad, uma palavra que significa "luta" em árabe e contém uma série de definições".
} 
PERcursos Linguísticos • Vitória (ES) •v. 10 •n. 25 • 2020 • ISSN: 2236-2592 • Dossiê:

\section{Discursos de resistência e corpos (re)existentes •}

flertando com o conceito de takfirismo - a excomunhão de pares muçulmanos baseada em sua suposta heresia, e uma injunção que quase sempre trazia consigo uma sentença de morte".

Essa proposta radical contra muçulmanos, especificamente os xiitas ${ }^{4}$, era contrária ao ponto de vista de Azzam, que tinha como inimigos apenas os infiéis do Ocidente. No final de 1989, Azzam e dois filhos morreram, ao serem atingidos por uma bomba. Weiss e Hassan (2015) relatam que um mês depois chegou a Peshawar (Paquistão), integrando um grupo que veio se juntar à Al Qaeda, Abu Musab al-Zarqawi, que alguns anos mais tarde ajudaria a fundar o Islamic State of Iraq and al-Sham (ISIS). Ele também se tornaria conhecido como "sheik das chacinas", por seu método de decapitar prisioneiros e postar vídeos e fotos dessas execuções nas redes sociais.

O relacionamento de bin Laden com Zarqawi foi conturbado desde o início, tendo em vista que o líder da Al Qaeda não aprovava medidas extremas contra os xiitas e os governos islâmicos da região. Fonseca e Lasmar (2017, p. 53) relatam que "para Zarqawi, esses governos teriam se desviado do que entendia ser o "verdadeiro Islã” e por isso deveriam ser tratados como governos apóstatas e derrubados".

A origem e a formação de Zarqawi revelam um pouco do seu comportamento. Segundo Weiss e Hassan (2015, p. 18), o jordaniano, cujo nome de batismo é Ahmad Fadhil Nazzal alKhalayalah, "foi um estudante pouco promissor e semianalfabeto em árabe, vindo a abandonar os estudos em 1984, no mesmo ano que seu pai morreu, e assumindo imediatamente uma vida de crimes".

Zarqawi chegou a ser preso por posse de drogas e ataque sexual. Preocupada com o futuro do filho, sua mãe o matriculou em cursos religiosos na Mesquita Al-Husayn, em Amã. Weiss e Hassan (2015) comentam que a experiência foi, relativamente, transformadora, pois o jordaniano se encantou com a fé. Porém, optou pelo salafismo radical e, a partir daí, se filiou a grupos extremistas.

Um dos campos de treinamento que Zarqawi frequentou, no Afeganistão, foi o mesmo por onde passou Khalid Sheikh Mohammed que, segundo Fonseca e Lasmar (2017), teria sido o mentor dos ataques de 11 de setembro. Depois desse fatídico atentado e da caçada humana

\footnotetext{
${ }^{4} \mathrm{O}$ grande cisma entre sunitas e xiitas ocorreu em 632, quando da morte do profeta Maomé, já que os fiéis não estavam de acordo quanto à escolha de um califa (sucessor). O genro do Profeta, Ali, reivindicou o direito de sucessão, alegando ser esse o desejo de Maomé. Aqueles que o apoiavam foram denominados xiitas. Os sunitas, que representam $85 \%$ da comunidade muçulmana no mundo, venceram a disputa, argumentando que o califa deveria ser escolhido pela comunidade islâmica.
} 
PERcursos Linguísticos • Vitória (ES) •v. 10 •n. 25 • 2020 • ISSN: 2236-2592 • Dossiê:

\title{
Discursos de resistência e corpos (re)existentes •
}

que o presidente George Bush empreendeu contra a Al Qaeda, invadindo o Iraque, em 2003, bin Laden viu que não tinha alternativa se não convocar Zarqawi para suas fileiras.

Armstrong (2002) avalia que a associação que bin Laden e os responsáveis pelos atentados de 11 de setembro fazem da violência ao Islamismo é equivocada. Mesmo tendo se valido da jihad na fase inicial da instituição da religião, o profeta Maomé mudou sua posição em relação à violência. A autora (2002, p. 13) esclarece que "a própria palavra islam, que significa "submissão" existencial de todo o seu ser a Deus, exigida dos muçulmanos, está relacionada a salam, "paz"”.

Weiss e Hassan (2015, p. 39) relatam que, em outubro de 2003, bin Laden convocou os mujahidin $^{5}$ estrangeiros para se engajarem na sua jihad. De acordo com os autores, nessa ocasião os "Saddamistas" já tinham criado trajetos seguros, chamados de "corredores de ratos", para levar esses voluntários estrangeiros ao Iraque. Trataremos mais da captação de voluntários quando formos analisar nosso corpus.

Zarqawi prestou juramento de obediência a bin Laden, em 2004, conforme Fonseca e Lasmar (2017). Mesmo tendo propostas de atuação diferentes, foi uma espécie de "casamento de conveniência”. Ao primeiro interessavam os recursos financeiros e o poder de recrutamento do líder da Al Qaeda, enquanto para esse o jordaniano poderia contribuir com seu destemor e poder de mobilização na luta contra os norte-americanos. Os autores $(2017$, p. 59) comentam que "Zarqawi passou a conduzir sistematicamente ataques suicidas contra tropas norteamericanas e xiitas com a utilização de homens bomba e "veículos bomba"”.

Além de alvos diferentes dos de bin Laden, Zarqawi usava uma estratégia de comunicação mais agressiva que, segundo estudiosos, ajudou na captação de voluntários:

\begin{abstract}
Zarqawi iniciou o uso da internet para a propaganda de sua "causa" de uma maneira nunca antes alcançada pela Al Qaeda. Suas novas técnicas de apelo pela internet conseguiram atrair milhares de combatentes estrangeiros, principalmente de países árabes (STERN; BERGER, 2015a). Ao contrário da organização de Bin Laden, acostumada a reproduzir longos e entediantes discursos, Zarqawi postava vídeos de ataques terroristas e suas primeiras decapitações. (FONSECA \& LASMAR, 2017, p. $60)$.
\end{abstract}

No curto período em que atuou na Al Qaeda, já que foi morto por tropas norteamericanas em 2006, Zarqawi implantou a nova estrutura do grupo que se tornou conhecido como Estado Islâmico ou Islamic State of Iraq and the al-Sham (ISIS) ou Islamic State of Iraq and the Levant (Isil) ou Daesh. Optamos por usar o termo Estado Islâmico por considerar ser o

\footnotetext{
${ }^{5}$ Mujahidin são pessoas que lutam em favor do Islã. O termo foi usado pelos próprios combatentes que lutaram no Afeganistão contra os soviéticos na década de 1980 e, desde então, passou a fazer parte do vocabulário "jihadista", como forma de mistificar e romantizar a figura do militante combatente.
} 
PERcursos Linguísticos • Vitória (ES) •v. 10 •n. 25 • 2020 • ISSN: 2236-2592 • Dossiê:

\section{Discursos de resistência e corpos (re)existentes •}

mais divulgado pela mídia de referência e, por esse motivo, tornar-se o mais conhecido no mundo.

Novas lideranças dos grupos terroristas foram erigidas e outros sequestros e execuções, postadas em suas redes sociais, ocorreram nos anos subsequentes. A caçada a bin Laden, apontado pelo Governo norte-americano como responsável pelos atentados de 11 de setembro, prosseguiu até a sua morte, em 2011. Seu sucessor, à frente da Al Qaeda, foi al-Zawahiri, porém o grupo já não tinha a mesma força do início dos anos 2000.

O modelo de grupo terrorista mais radical e com uso da mídia digital, criado por Zarqawi, fizera escola e outros líderes se encarregaram de dar continuidade a ele. Weiss e Hassan (2015) relatam que, em 28 de junho de 2014, Abu Bakr al-Baghdadi, ungido como Califa Ibraim, proclama o nascimento do Estado Islâmico (Califado). No ano seguinte, Fonseca e Lasmar (2017) afirmam terem sido realizados mais de 50 atentados, fora do eixo Iraque/Síria, que resultaram na morte de mais de 1 mil civis. Os países mais atingidos foram França, Bélgica, Iraque, Turquia e Indonésia.

A morte de al-Baghdadi se deu em outubro de 2019, quando ele detonou seu cinto de explosivos, ao ser localizado por tropas americanas em um túnel, na Síria. Por meio de suas redes sociais, o Estado Islâmico reconheceu a morte de seu líder e anunciou que seu sucessor era Abu Ibrahim al-Hashemi al-Quraishi. Como podemos observar, mesmo com os Estados Unidos tendo anunciado a vitória definitiva sobre o Califado, o Estado Islâmico não parece disposto a encerrar suas atividades.

\section{Quadro teórico}

Acreditamos que, para conseguir analisar os textos que representantes do Estado Islâmico postam nas suas redes sociais, geralmente para justificarem suas ações violentas, fazer reverência a Maomé e captar voluntários, precisaremos nos valer de pelo menos três elementos do universo linguístico/discursivo: profecia/apocalipse, polêmica e discurso propagandístico/incitação. Mesmo tendo significados próprios e aplicações autônomas, eles possuem conexões discursivas e permanecem imbricados, quando buscamos entender a dinâmica de funcionamento do Estado Islâmico.

Grosso modo, o Estado Islâmico é formado por um grupo de pessoas, que se diz filiado ao Islamismo. O fundador do Islamismo, no século VII d.C., foi Maomé, que se autointitulou o único profeta de Allah. Por meio de textos, com caráter profético, o Estado Islâmico parece querer estimular seus seguidores a desenvolverem ações violentas, que levem ao apocalipse e 
PERcursos Linguísticos • Vitória (ES) •v. 10 •n. 25 • 2020 • ISSN: 2236-2592 • Dossiê:

\section{Discursos de resistência e corpos (re)existentes •}

ao martírio. Na divulgação de alguns de seus atentados terroristas e outros atos de violência pelas redes sociais, os integrantes do grupo se valem da erística, um dos recursos da polêmica, enquanto elemento da retórica e da argumentação.

Para divulgação de suas ações violentas, que cientistas e estudiosos da religião acreditam ter entre os seus propósitos a captação de novos voluntários; e de suas mensagens, também com caráter persuasivo, ao ressaltarem as injustiças econômicas e sociais cometidas pelos países ricos em relação aos países pobres, o Estado Islâmico recorre ao discurso propagandístico. Com caráter profético e polêmico, essas mensagens, em forma de imagens e textos, têm se mostrado capazes de atrair pessoas de várias partes do mundo. A maioria se mostra insatisfeita com o atual sistema político e econômico, no qual um grupo de 20 países detém a maior parte do capital do planeta e o restante se divide entre os que garantem uma vida simples para sua população e aqueles que não conseguem oferecer nem os direitos básicos.

Segundo Fonseca e Lasmar (2017), entre os fatores que estão facilitando a captação, principalmente de jovens europeus pelo Estado Islâmico, estão as altas taxas de desemprego e as precárias condições de trabalho. Há também jovens muçulmanos que, mesmo vivendo em alguns desses países há muitos anos, não se sentem integrados à sociedade local. Conforme depoimentos de alguns que retornaram para casa, depois de algum tempo, "eles decidiram migrar para o Estado Islâmico para começar uma vida nova sob outra identidade. Buscavam, assim, encontrar um sentido para suas vidas e se refugiarem em um local onde seriam aceitos como "iguais" (COOLSAET, 2015b apud FONSECA; LASMAR, 2017, p. 95).

Já a antropóloga Dounia Bouzar (2016), que acompanhou 130 famílias francesas cujos filhos se engajaram no Estado Islâmico, informa que apenas $20 \%$ deles tinham convicção religiosa. Ela comenta que os grupos radicais visam, principalmente, jovens idealistas, sem ligação com o Islã, por considerarem que assim a doutrinação se torna mais fácil. As famílias são, em sua maioria, de classes média e alta. A doutrinação, conforme a antropóloga, é feita por meio de vídeos com a teoria da conspiração, as imagens subliminares de videogames e imagens chocantes de violência. "O islã radical não passa pelas mesquitas”, salienta Bouzar (2016, p. $52)$.

Para completar, dentro do discurso propagandístico existe um elemento que é fundamental para fazer com que os integrantes do Estado Islâmico aprendam a desenvolver a violência e colocar seus mecanismos em prática: a incitação à ação. Segundo Emediato (2019), se na propaganda de um eletrodoméstico ou na preparação de uma receita culinária, as pessoas são incitadas a montar o aparelho ou misturar corretamente os ingredientes, com o objetivo de 
PERcursos Linguísticos • Vitória (ES) •v. 10 •n. 25 • 2020 • ISSN: 2236-2592 • Dossiê:

Discursos de resistência e corpos (re)existentes •

usá-lo ou preparar o prato; no caso dos grupos terroristas, a incitação consiste em ensinar seus integrantes a montarem uma arma ou uma bomba; partindo, em seguida, para a ação, quando são convencidos a usá-las para matar e, em alguns casos, se matarem.

Discorreremos agora sobre cada um desses elementos, para que possamos entender seus conceitos no campo da Linguística, assim como sua utilização na área da Análise do Discurso. Aproveitaremos para, a partir deles, definir algumas categorias de análise, que nos permitirão investigar o nosso corpus.

\section{Profetas do apocalipse}

Alguns dos líderes do Estado Islâmico e também da Al Qaeda, que consideramos ter dado origem a ele, estudaram as leis islâmicas, aplicando-as de forma rígida e distorcida, conforme alguns especialistas. De acordo com Armstrong (2002), eles fizeram o mesmo com os ensinamentos do profeta Maomé, fundador do Islamismo. O profetismo é uma marca presente nos textos divulgados pelo grupo, provavelmente com a intenção de reforçar o caráter religioso de suas ações.

Segundo Rabatel (2019), a profecia tem uma conotação religiosa e outra temporal. Com base nos dicionários Tesoureiro Informatizado da Língua Francesa (TLFi) e a Grande Larousse da Língua Francesa (GLLF), o autor (2019, p. 55) define "profecia", no seu aspecto religioso, como "o anúncio de eventos futuros por uma pessoa sob inspiração divina".

Já os significados do item lexical "profeta" nos Dicionários utilizados por Rabatel (2019, p. 55) são: "aquele que é o intérprete dos deuses "; 2. "(na Bíblia) Aquele a quem Deus escolheu transmitir e explicar sua vontade" (TLFi). É por esse segundo significado que o TLFi evoca falsos profetas e cita a máxima de que "ninguém é profeta em seu país".

Entendemos que a figura do "profeta” foi a forma didática que Rabatel (2019) encontrou para nos falar do enunciador no seu papel de homo narrans. Ele reúne qualidades, como empatia e credibilidade, que o credenciam para assumir o papel de "profeta". Sobre a máxima de que “ninguém é profeta em seu país", lembramos o caso de Maomé. Fundador do Islamismo, no século VII d.C., ele precisou sair de Meca, sua terra-natal, onde era criticado e até ameaçado por revelar suas profecias e tentar estabelecer as normas do Islamismo. Junto com sua família e um grupo de seguidores, Maomé se mudou para Medina, onde conseguiu conquistar mais adeptos e implementar a nova religião.

O evento profetizado (o enunciado), de acordo com o autor (2019), faz sentido, não apenas por ser extraordinário, mas também porque imediatamente coloca a questão da ação (o 
PERcursos Linguísticos • Vitória (ES) •v. 10 •n. 25 • 2020 • ISSN: 2236-2592 • Dossiê:

\section{Discursos de resistência e corpos (re)existentes •}

agir) para a sobrevivência individual e coletiva. Observamos que algumas enunciações feitas pelo Estado Islâmico, por meio de textos e imagens, têm o claro objetivo de levar seus voluntários, que na concepção de Rabatel são chamados de testemunhas proféticas, a agirem contra aqueles que são considerados infiéis.

Existe uma diferença entre profeta e testemunha profética. O profeta se autointitula como "o escolhido", ao passo que a testemunha profética é arregimentada. Rabatel (2019, p. 61) explica que "enquanto o profeta é chamado a testemunhar uma verdade imanente, a testemunha não é escolhida, mas conduzida por circunstâncias históricas, frequentemente independentes de sua vontade de dizer o que viu, experimentou".

Isso significa que o profeta afirma ter se envolvido diretamente com os fatos. É como se ele tivesse recebido uma distinção divina. $\mathrm{O}$ profeta procura demonstrar que vivenciou os fatos e, depois, os enuncia. Entre os enunciadores do Estado Islâmico, há aqueles que garantem ter o poder de distinguir os infiéis e inimigos do Islamismo, propondo ações para eliminá-los ou, no mínimo, expulsá-los dos territórios sagrados.

A figura do homo narrans e o conceito de Ponto de Vista (PDV), também desenvolvidos por Rabatel, serão fundamentais para que o profeta obtenha êxito nessa sua empreitada de fazer com que a testemunha absorva a profecia, transformando-se numa testemunha profética. Rabatel (2016, p. 24) explica que "homo narrans é, finalmente, o homem com mil pontos de vista, que sabe empatizar seus personagens e simpatizar com eles, para o maior proveito de seu auditório". O autor acrescenta que o homo narrans é um sobre-enunciador, que fala com os outros e por sobre a fala deles. Isso nos faz deduzir que o profeta é um homo narrans. Essa figura singular tem mil pontos de vista, entre os quais pode estar a profecia.

Um dos objetivos do profeta, enquanto sobre-enunciador, é persuadir as testemunhas proféticas a agirem para atingir o apocalipse:

\footnotetext{
Apocalipse quer dizer revelação $(1,1)$. Este livro, portanto, é uma mensagem reveladora. $\mathrm{O}$ autor procura revelar o mistério $(10,7)$ do que está acontecendo e do que vai acontecer: Deus vai agir na história, julgando e destruindo o mal, para implantar definitivamente o seu Reino entre os homens $(11,15)$. (BÍBLIA PASTORAL, Apocalipse de São João, Introdução, 1990, p. 1.589).
}

A conjuntura política do período em que João escreveu o Apocalipse era bastante opressora. Os cristãos estavam temerosos com o que lhes poderia acontecer, principalmente depois da perseguição que sofreram durante o império de Nero (54-68 d.C.). O texto é de difícil compreensão, já que o autor usa imagens, símbolos, figura e números misteriosos, em forma de código. O objetivo de João ([Séc. I d.C.],1990, p. 1.589) era o de preparar as comunidades 
PERcursos Linguísticos • Vitória (ES) •v. 10 •n. 25 • 2020 • ISSN: 2236-2592 • Dossiê:

\section{Discursos de resistência e corpos (re)existentes •}

cristãs, para que elas se fortalecessem por meio do testemunho de Jesus e resistissem "às perseguições e desenvolvendo ação libertadora, que manifestasse ao mesmo tempo decidida crítica à situação de opressão e firme esperança de uma sociedade nova".

O Islamismo prega a existência de um Deus, chamado de Allah, e o Alcorão é resultado de revelações feitas a Maomé. O Apocalipse parece ter inspirado o profeta. Conforme Fonseca e Lasmar (2017, p. 62), “a narrativa escatológica e apocalíptica iniciada por Zarqawi, (...) foi desenvolvida e bastante aprimorada pela atual liderança do Isis. Essa narrativa tem sido capaz de seduzir ainda mais estrangeiros, inclusive ocidentais nascidos e criados no Ocidente”.

Para alguns voluntários do Estado Islâmico vale qualquer tipo de ação, mesmo as mais radicais que impliquem em dar fim à própria vida, para colocar em prática as ordens dos profetas do apocalipse:

\footnotetext{
Estrangeiros são utilizados em operações suicidas usando coletes ou automóveis explosivos, ou em operações individuais de alto risco. Especialmente no Iraque e Síria, muitos cidadãos árabes de países próximos são utilizados para fins suicidas, como sauditas e tunisianos, obcecados pela ideia do martírio (BARRET, 2014a). (FONSECA; LASMAR, 2017, p. 74).
}

Estudiosos do Islamismo esclarecem que homens e mulheres-bombas recebem um status especial entre seus pares dos grupos radicais. O automartírio, nos ataques contra os infiéis e os inimigos da "causa", associado de forma distorcida ao Islamismo, faz com que essas pessoas permaneçam em alta conta entre os outros seguidores. Eles acreditam que homens e mulheres-bombas são distinguidos com a entrada franqueada no paraíso ou céu.

\section{Uso da polêmica com propósitos persuasivos}

A polêmica, como elemento da retórica e da argumentação, tem sido trabalhada por Amossy (2017), que leva em conta estudos anteriores realizados principalmente por Schopenhauer (2009), Dascal (1998), Kerbrat-Orecchioni (1980) e Coser ([1956]1964; 1970). A autora avalia que elementos com o dissenso e a erística, próprios da polêmica e contrários ao acordo, à heurística e ao diálogo, possuem efeitos persuasivos. Ao verificarmos a atração que os textos e imagens com tons extremamente violentos, como os vídeos de decapitações divulgados pelo Estado Islâmico, concordamos com os resultados dos estudos de Amossy e de outros teóricos, que apostam na eficácia persuasiva da polêmica.

Os acordos que, como explicam Perelman e Olbrechts-Tyteca (1996), podem levar o orador a interagir e tentar persuadir o auditório, não fazem parte das ações retóricas/argumentativas do Estado Islâmico em relação aos infiéis. Para tentar estabelecer 
PERcursos Linguísticos • Vitória (ES) •v. 10 •n. 25 • 2020 • ISSN: 2236-2592 • Dossiê:

\section{Discursos de resistência e corpos (re)existentes •}

acordos seriam necessários diálogos e o uso de argumentos, porém o grupo parece descartar essa possibilidade. O dissenso, como um dos elementos da polêmica, é a opção escolhida pela facção.

Amossy (2017, p. 18) comenta que “dissensão está, então, relacionada a uma discordância, como uma profunda, até mesmo violenta, diferença de opiniões". O dissenso é justificado pelo Estado Islâmico em virtude das invasões de países do Oriente Médio por tropas russas, norte-americanas e de outros países europeus. O grupo também mantém a dissensão em relação aos xiitas e governantes de países do Oriente Médio, que consideram ter traído o Islamismo.

Como observa Amossy, existem cenários e espaços públicos apropriados para desenvolvimento da polêmica. A autora (2017, p. 8) assinala que "evidentemente, pode-se explicar o fenômeno pela incapacidade dos cidadãos, como pessoas políticas, de seguir as regras do debate racional, ou ainda pela curiosidade insana que o público das mídias tem pelo espetáculo da violência verbal".

O recurso retórico/argumentativo utilizado para inflamar a polêmica é a erística, que privilegia as discussões acaloradas, os insultos e toda sorte de agressões verbais. Podemos denominá-la como "combustível da discórdia":

Sob sua égide, o debate se torna um combate sem escrúpulos e sem regras, uma arte da disputa em si mesma. A partir de então, todos os golpes são permitidos. "A erística”, relembra Marc Angenot (2008, p. 52), é "uma arte (...) que não recuará diante dos piores expedientes, nem ante os insultos, os sarcasmos, a ridicularização. (AMOSSY, 2017, p. 21).

Os enunciadores, que se valem da erística, descartam a possibilidade de diálogo civilizado e baseado em argumentos, como se faz na heurística. Sua opção pelos insultos e agressões verbais parece querer convocar os interlocutores para uma espécie de "ringue" de troca de ofensas e golpes baixos. A ideia é a de que aquele que gritar mais e utilizar ofensas mais fortes sairá vencedor da contenda. Schopenhauer (2009, p. 9 apud Amossy, 2017, p. 38) salienta que "disso resulta, em geral, que aquele que se envolve em uma controvérsia luta não pela verdade, mas por sua proposição".

Algumas vezes, o polemista radical convoca a figura do demônio para fortalecer o seu enunciado e aterrorizar os enunciatários. Os adversários ou inimigos são apresentados como símbolos do "mal absoluto", com intuito de gerar o medo e até o ódio. Amossy (2017, p. 60) assinala que "o outro demonizado só pode ser excluído, porque é impensável estabelecer um diálogo com Satã em pessoa". 
PERcursos Linguísticos • Vitória (ES) •v. 10 •n. 25 • 2020 • ISSN: 2236-2592 • Dossiê:

Discursos de resistência e corpos (re)existentes •

Líderes políticos ou religiosos, assim como grupos radicais, costumam usar a figura do demônio com o intuito de angariar apoio à sua causa. Amossy $(2017$, p. 60) se recorda que o ex-presidente da Venezuela, Hugo Chaves, num pronunciamento, em 2006, na sede das Nações Unidas, se referiu ao então presidente dos Estados Unidos, George W. Bush, seu inimigo político, com essa conotação: "E o diabo veio aqui ontem. Ontem o diabo veio aqui. Justo aqui (ele aponta para si mesmo). E ainda cheira a enxofre hoje".

\section{Discurso propagandístico e a incitação}

Uma das características do Estado Islâmico e que o diferencia de outros grupos radicais, como a Al Qaeda, é uso da internet, principalmente das redes sociais, para postar textos e vídeos justificando suas ações e também execuções sumárias de oficiais do Exército e profissionais da imprensa oriundos de países como os Estados Unidos e outros da Europa. Entendemos que, ao agir dessa maneira, o grupo está fazendo uso do discurso propagandístico. Um dos objetivos parece ser o de difundir o terror virtual entre os governantes e a população dos países considerados inimigos ou infiéis. O segundo objetivo é o de gerar identificação entre pessoas que possam simpatizar com a "causa", por se sentirem injustiçadas pela conjuntura política e econômica atuais, levando-as, num segundo momento, a quererem se engajar na luta desses grupos radicais.

Para Charaudeau (2010), o discurso propagandístico pode ser enquadrado como um discurso de incitação, que procura motivar as pessoas a "fazerem" alguma coisa. Ele é composto de quatro elementos, que o levam a funcionar. O primeiro é a presença do "eu", ou seja, o sujeito que, sem impor autoridade, usa uma estratégia de "fazer crer" ao outro sujeito "tu", que o "eu” idealiza como "dever crer". O segundo elemento é a instância de produção, individual ou coletiva, muitas vezes imputável quanto à responsabilidade do produto gerado.

O terceiro elemento indicado por Charaudeau (2010) é o dispositivo de difusão, que tem como alvo uma instância coletiva. No caso do Estado Islâmico, o dispositivo primário são as redes sociais, porém muitas vezes esse material também é propagado pela mídia de referência, ampliando a sua difusão. O quarto elemento diz respeito ao uso do duplo esquema cognitivo, narrativo e argumentativo, que será fundamental para que a instância de recepção ative sua posição de "dever crer".

$\mathrm{Na}$ opinião de Charaudeau (2010), embora o esquema argumentativo tenha um propósito persuasivo mais explícito, o uso do modo narrativo pode ser mais eficiente no 
PERcursos Linguísticos • Vitória (ES) •v. 10 •n. 25 • 2020 • ISSN: 2236-2592 • Dossiê:

Discursos de resistência e corpos (re)existentes •

discurso propagandístico. O autor (2010, p. 63) explica que "uma narração não impõe nada, ela apenas propõe um imaginário de busca cujo interlocutor poderia, se quisesse, ser o herói, sob a forma de uma narrativa".

O discurso propagandístico também tem propósitos de profecia:

\begin{abstract}
Ela consiste em levar as massas a aderirem a um projeto de idealização social ou humana. Para isso: 1) deve-se poder referir-se a uma fala de revelação, porque a verdade reside nesta fala; 2 ) esta fala de revelação deve prometer, de uma maneira ou de outra, "dias melhores"; 3) a instância propagandista deve ter um estatuto de representante simbólico autorizado como portador desta fala (profeta/o pequeno pai do povo); ela deve dispor de grandes meios de comunicação (o cinema soviético, os espetáculos nazistas); 4) a instância "público" é levada a reconhecer-se desejosa de um absoluto. (CHARAUDEAU, 2010, p. 74-75).
\end{abstract}

A estratégia de propaganda do Estado Islâmico se encaixa como uma luva nesses propósitos profetizantes descritos por Charaudeau. Para completar, Emediato (2019) comenta que o recurso da incitação à ação, utilizado no discurso publicitário para levar o público a montar um eletrodoméstico ou executar uma receita culinária, serve para que grupos radicais orientem os voluntários, que conseguem captar por meio das redes sociais, a aprenderem e se convencerem a montar e utilizar armas e bombas para matar e também se matarem.

Pereira (2008) acrescenta que o discurso publicitário, em algumas situações, faz uso de máscaras dentro da noção bakhtiniana. Elas podem ser entendidas como metáforas de identidades. O objetivo não é de ocultação da face, mas como uma imagem de identidade frente a outrem. A autora $(2008$, p. 30) também registra nesse discurso a presença de ideologia e da formação discursiva que, pela concepção de Foucault, estabelece "relações de antagonismo, aliança ou dominação".

A condução da violência que leva à sujeição no campo social é outra característica desse gênero discursivo:

\footnotetext{
Simultaneamente, o discurso publicitário também é, portanto, retenção da violência das relações sociais exteriores a suas próprias convenções: exatamente por isso, a publicidade é retenção obrigatória de sua própria violência, a de seu propósito que, em última instância, sempre verifica os interesses conflitantes do campo institucional ao qual está organicamente ligada mas que, no contexto, transforma em modalidades de sedução, suas modalidades de sujeição. (DAHLET, 1995, p. 19).
}

Interessante observar como o Estado Islâmico se vale de todos esses recursos do discurso propagandístico e, em alguns casos, do discurso publicitário, para tentar alcançar seus objetivos. Em seus textos ou vídeos, o grupo recorre ao modo narrativo e às formações discursivas para mostrar o sofrimento que países como os Estados Unidos e outros da Europa impõem às famílias de países do Oriente Médio. Isso parece gerar um efeito de identificação, 
PERcursos Linguísticos • Vitória (ES) •v. 10 •n. 25 • 2020 • ISSN: 2236-2592 • Dossiê:

Discursos de resistência e corpos (re)existentes •

que faz com que pessoas de vários países se engajem nessa luta. Por meio da incitação à ação, elas são treinadas e aprendem a usar armas para matar e se matarem.

\section{Metodologia, categorias de análise e corpus}

Encontrar textos produzidos pelo Estado Islâmico não é uma tarefa muito simples. Pesquisamos nas redes sociais abertas e também na deep web, mas sem sucesso. Foi a partir de uma conversa com o professor e escritor Guilherme Damasceno Fonseca, um dos autores do livro "Passaporte para o terror - os voluntários do Estado Islâmico" (2017), que chegamos até o site www.jihadology.net.

Nosso corpus é composto por um conjunto de três textos que coletamos no site www.jihadology.net. Seu fundador, o pesquisador e escritor Aaron Zelin, estabeleceu parceria com o jornalista Jawad al-Tamimi, responsável por um blog que disponibiliza textos e vídeos do grupo Exército de Khalid bin al-Waleed (JKBW), afiliado ao Estado Islâmico (EI). Fundado em 2016, o grupo JKBW atua no sul da Síria e, em 2018, teve seu nome alterado para Província de Hawran.

Os critérios para seleção do corpus foram baseados na relevância do material, tendo em vista que os excertos estão relacionados com a estratégia do Estado Islâmico de criar uma relação de empatia e identificação com seus interlocutores. Nosso corpus comprova o esforço de comunicação do grupo radical no sentido de ganhar a confiança das pessoas e tentar captar adeptos para a sua causa.

Criamos três categorias de análise, baseadas em nosso referencial teórico, que utilizaremos para analisar o corpus selecionado. Elas foram estabelecidas de acordo com elementos da profecia/apocalipse, polêmica e discurso propagandístico/incitação. No que tange à profecia/apocalipse, observaremos o tom profético dos textos, que tenham propósitos apocalípticos e que, de algum modo, possam incentivar o martírio. Na parte da polêmica, procuraremos verificar marcas de dissenso, violência verbal e outros elementos da erística. Por fim, no que diz respeito ao discurso propagandístico, tentaremos identificar itens lexicais que induzam à incitação e à divulgação de propósitos, identificação e engajamento à causa do Estado Islâmico.

A metodologia que utilizamos foi a de ler a coleção de textos no site www.jihadology.net, selecionar os três que consideramos mais representativos e que se enquadraram nos quesitos de profecia, polêmica e propaganda. Em seguida, analisamos o material, observando as marcas que pudessem incluí-los em nossas categorias de análise. Em 
PERcursos Linguísticos • Vitória (ES) •v. 10 •n. 25 • 2020 • ISSN: 2236-2592 • Dossiê:

\section{Discursos de resistência e corpos (re)existentes •}

virtude da exiguidade de espaço, não pudemos estender muito a análise, porém procuramos realizá-la da forma mais aprofundada possível.

O primeiro excerto que analisaremos foi retirado de uma convocação feita pelo setor de Relações Públicas do grupo Província de Hawran aos ex-moradores locais, para que retornassem às suas casas:

\section{Excerto 01}

Sabemos que a guerra que aconteceu entre os soldados do califado - que Deus o faça poderoso em tawheed - na bacia de Yarmouk e nas facções do Exército Livre, foi uma das razões pelas quais você deixou sua casa. Por isso, pedimos que você retorne a ela, e isso será através de Masakin Jalin. E recebê-lo na terra do Islã, pois nossos postos de controle estão abertos diante de você. E Deus é o administrador dos piedosos ${ }^{6}$. (Tradução nossa).

A opção do grupo/enunciador em utilizar o seu setor de Relações Públicas para fazer a convocação já dá um caráter propagandístico ao EXCERTO 01. O tom propagandístico prossegue quando o enunciatário, tratado de forma individual, é tranquilizado, quanto ao motivo que o levou a abandonar sua casa, e sobre a situação do momento, que leva a crer que o local está livre de conflitos. Como bom anfitrião, o grupo ressalta que as portas da "terra do Islã" estão abertas.

Também no EXCERTO 01 verificamos a presença de elementos do discurso profético. A referência aos "soldados do Califado" indica que foi cumprida a profecia de se criar um Califado, que o Estado Islâmico delimitou, em 2014, numa área entre o Iraque e a Síria. Ainda é utilizado o item lexical "taweed", que faz referência a Allah, o Deus do Islamismo, cujo único profeta é Maomé. A figura de Deus, apresentada como “administrador dos piedosos" confere ao próprio Estado Islâmico o caráter do acolhimento e da bondade. O que não é revelado, conforme observam alguns estudiosos do grupo, é que o interesse maior para que as famílias retornassem às suas casas era para que auxiliassem nas atividades de rotina, pagassem tributos e servissem de escudo para o EI.

No EXCERTO 02, extraído de um texto denominado "Califado do Estado Islâmico: metodologia profética" (tradução nossa), observamos situações discursivas que indicam o uso da polêmica e da profecia:

\section{Excerto 02}

Depois do discurso do sermão dos irmãos na sexta-feira - esta semana foi compensado - foi feito um discurso ao povo sobre o perigo dos túmulos elevados para Tawheed. Então pedimos a todos que fossem conosco ao cemitério

\footnotetext{
${ }^{6}$ We know that the war that has gone on between the soldiers of the Caliphate- may God make it mighty in tawheed- in the Yarmouk Basin and the factions of the Free Army, has been a reason why you have left your homes. Therefore we call on you to return to them, and that will be through Masakin Jalin. And we welcome you in the land of Islam, and our checkpoints are open before you. (Islamic State - Public Relation, 2018).
} 
PERcursos Linguísticos • Vitória (ES) •v. 10 •n. 25 • 2020 • ISSN: 2236-2592 • Dossiê:

\section{Discursos de resistência e corpos (re)existentes •}

para nivelá-lo, para que todos participassem da destruição, nivelamento e remoção desses atos condenados, e louvassem Deus ${ }^{7}$. (Tradução nossa).

A intolerância religiosa pode ser caracterizada como um recurso da polêmica, enquanto elemento da retórica/argumentação. Pelo que observamos nas entrelinhas do texto, em Hawran deve existir um cemitério de cristãos, onde provavelmente há imagens de Jesus, Maria ou dos santos sobre os túmulos. Os muçulmanos consideram isso idolatria. O sermão alertou os moradores sobre o problema e, depois, eles foram conduzidos ao cemitério para "destruir, nivelar e remover os atos condenados". Ao que tudo indica, não existe possibilidade de diálogo ou acordo com as famílias cristãs, o que cria o dissenso.

No que tange aos aspectos proféticos do EXCERTO 02, observem que antes do pronunciamento ao povo, foi realizado um sermão para os integrantes do grupo. $\mathrm{Na}$ metodologia profética proposta por Rabatel (2019), o profeta, que é provavelmente o líder máximo do EI no local ou alguém mais preparado, no âmbito religioso, que tenha sido indicado por ele, enuncia a mensagem profética. O propósito deve ser o de reforçar a sharia (leis islâmicas) entre as testemunhas proféticas, que no caso são os integrantes do grupo.

No EXCERTO 03, extraído do comunicado "Início da regulação da geração de energia elétrica: Província de Ninawa" (tradução nossa), constatamos a presença do discurso propagandístico e da polêmica:

\section{Excerto 03}

A operação real será de 8 horas a partir das 13:00 às 16:00, e 17:00 às 20:00 e 21:00 às 23:00. Durante o horário de operação, no caso de haver eletricidade na rede nacional, o período será prorrogado até depois da meia-noite. (...) Responsabilizaremos todos os que violarem o horário de funcionamento ou a folga na operação e tomaremos medidas firmes contra aqueles que não cumprirem ${ }^{8}$. (Tradução nossa).

Fonseca e Lasmar (2017) comentam que o Estado Islâmico costuma agir como um gestor público, concedendo benefícios à população das cidades e províncias que ocupa. No caso do EXCERTO 03, verificamos que o grupo oferece e regula o uso da energia elétrica. Para conquistar simpatia, oferece até uma ampliação no horário de utilização, caso a rede nacional permita. O efeito propagandístico é o de tornar o grupo mais simpático junto à população local.

\footnotetext{
${ }^{7}$ After the sermon address of the brothers on Friday- this week was on compensation- a speech was given to the people about the danger of the elevated graves to Tawheed. Then we asked them all to go with us to the graveyard to level it so all should participate in destroying, levelling and removing these condemned acts, and praise be to God.(Islamic State - Caliphate on teh prophetic metodology, 2019).

${ }^{8}$ Real operation will be 8 hours beginning from 1 p.m. until 4 p.m., and 5 p.m. until 8 p.m. and 9 p.m. until 11 p.m. During operation hours, in the event that there is national grid electricity, the period will be extended until after midnight. (...) We will hold accountable all who violate the hours of operation or slack in operation and we will take firm measures against those who fall short. (Early regulations on electricity generation: Ninawa Province, 2019).
} 
PERcursos Linguísticos • Vitória (ES) •v. 10 •n. 25 • 2020 • ISSN: 2236-2592 • Dossiê:

Discursos de resistência e corpos (re)existentes •

O tom ameaçador na última frase do EXCERTO - 03 é uma marca da erística. Ela costuma guiar a polêmica e se caracteriza por insultos, agressões verbais e toda sorte de impropérios. Quando o enunciador avisa que "tomaremos medidas firmes contra aqueles que não cumprirem (as orientações quanto aos horários para se usar a energia elétrica)", identificamos a presença da erística.

\section{Considerações finais}

Verificamos, por meio da análise do corpus indicado, que a nossa hipótese de que o grupo Estado Islâmico (EI) utiliza recursos como o discurso profético, a polêmica e o discurso propagandístico para difundir suas ações e captar voluntários dispostos a se engajarem na sua causa, foi confirmada. Usando uma mensagem, que mistura indignação contra países ricos que subjugam países do Oriente Médio, principalmente os de maioria muçulmana, e a convocação de pessoas que também se sintam exploradas e injustiçadas para viverem num espaço (Califado), no qual esses problemas serão resolvidos, o grupo chegou a reunir entre 10 mil e 30 mil seguidores, muitos deles estrangeiros. A estratégia de divulgação contemporânea, por meio das redes sociais, favorece essa captação.

No nosso corpus, observamos que o grupo Província de Hawran, pertencente ao Estado Islâmico, conta, inclusive, com um setor de Relações Públicas (EXCERTO 01). Num tom bastante cordial, as famílias que abandonaram suas casas por causa dos conflitos armados na região, são convidadas a retornarem. O Califado é mostrado como "terra do Islã" e Deus como "administrador da piedade".

Mesmo a utilização de medidas polêmicas e de intolerância, como podemos ver no EXCERTO 02, quando na sua metodologia profética o EI determina que o cemitério cristão tenha as imagens destruídas, consideramos que isso tem um caráter persuasivo, como acredita Amossy (2017). É provável que os simpatizantes do Islamismo possam ver esse tipo de ação como uma "limpeza" do espaço onde antes vigorava o Cristianismo e a adaptação do Califado, de acordo com a sharia.

Por fim, também acreditamos que a, aparentemente, simples nota com orientações sobre o uso da energia elétrica (EXCERTO 03) cumpre seu papel de divulgar o Estado Islâmico na função de um gestor público, que proporciona conforto aos moradores da Província. O rigor no cumprimento dos horários de utilização da energia elétrica e as ameaças àqueles que os descumprirem se enquadram na erística, que não deixa de ter tintas persuasivas, principalmente 
PERcursos Linguísticos • Vitória (ES) •v. 10 •n. 25 • 2020 • ISSN: 2236-2592 • Dossiê:

Discursos de resistência e corpos (re)existentes •

entre aqueles que consideram que o mundo ocidental vive um período de liberalismo exacerbado.

\section{Referências}

AMOSSY, R. Apologia da polêmica. São Paulo: Contexto, 2017.

ARMSTRONG, K. Maomé - uma biografia do profeta. São Paulo: Companhia das Letras, 2002.

BÍBLIA, E.P. Apocalipse. In: BÍBLIA. Sagrada Bíblia Católica - Edição Pastoral. Tradução, introdução e notas: Ivo Storniolo e Euclides Martins Balancin. São Paulo: Paulus Editora, 1990. P. 1.589-1.614.

BOUZAR, D. Os jovens franceses da jihad. In: FOTTORINO, E. Quem é o Estado Islâmico? - Compreendendo o novo terrorismo. Belo Horizonte: Autêntica Editora, 2016.

CHARAUDEAU, P. O discurso propagandista: uma tipologia. In: MACHADO, I. L.; MELLO, R (Orgs.). Análises do discurso hoje - volume 3. Rio de Janeiro: Nova Fronteira, 2010.

DAHLET, P. Reflexões sobre a prática publicitária. In: FARIAS, Y. O. O discurso publicitário - Instrumentos de Análise. Recife: Editora Universitária da UFPE, 1996.

EARLY REGULATIONS ON ELECTRICITY GENERATION: Ninawa Province. Jihadology.net, 2019. Disponivel em: https://islamicstatearchives.com/category/mosul/ - acesso em 16/04/2020.

EMEDIATO, W. Discurso de incitação à ação (apresentação). Núcleo de Análise do Discurso (NAD) da Faculdade de Letras da UFMG. Belo Horizonte: UFMG, 2019.

FONSECA, G. D.; LASMAR, J. M. Passaporte para o terror - Os voluntários do Estado Islâmico. Curitiba: Appris Editora, 2017.

ISLAMIC STATE - Caliphate on the prophetic metodology. Jihadology.net, 2019. Disponível em: https://islamicstatearchives.com/2019/10/07/sample-islamic-state-weekly-hisba-report/ - acesso em $06 / 03 / 2020$.

ISLAMIC STATE - Public Relations. Jihadology.net, 2018. Disponível em: http://www.aymennjawad.org/2018/06/jaysh-khalid-bin-al-waleed-public-relations - acesso em 16/04/2020.

MORIN, E. Tentando compreender. In: FOTTORINO, E. Quem é o Estado Islâmico? Compreendendo o novo terrorismo. Belo Horizonte: Autêntica Editora, 2016.

PEREIRA, R. C. Discurso e publicidade - Dos processos de identificação e alteridade pela propaganda brasileira. Niterói: Editora UFF, 2008. 
PERcursos Linguísticos • Vitória (ES) •v. 10 •n. 25 • 2020 • ISSN: 2236-2592 • Dossiê:

Discursos de resistência e corpos (re)existentes •

PERELMAN, C; OLBRECHTS-TYTECA, L. Tratado da argumentação - a nova retórica. São Paulo: Martins Fontes, 1996.

RABATEL, A. Homo narrans - por uma abordagem enunciativa e interacionista da narrativa. São Paulo: Cortez Editora, 2016.

RABATEL, A. Prophétic, fonction prophétique et témoignage prophétique. In: L'Analisi linguistica e Letteraria. Publicação da Facoltà de Scienze Linguistiche e Letterature Straniere. Università Cattolica del Sacro Cuore. Milão: Litografia Solari - Peschiera Borrondo. Ano XXVII, 01/2019, p. 55-80.

SUTTI, P.; RICARDO, S. As diversas faces do terrorismo. São Paulo: Harbra, 2003.

WEISS, M.; HASSAN, H. Estado Islâmico - Desvendando o exército do terror. São Paulo: Seoman, 2015. 